\title{
ポリフッ化ビニリデンの高温領域における 絶縁破壊とその数值計算による解析
}

\begin{tabular}{|c|c|c|c|c|c|c|}
\hline 正 & & 匹 & 田 & 政 & 幸 & (名古屋大) \\
\hline & 員 & 長 & 尾 & 雅 & 行 & （豐橋技科大） \\
\hline & 宣 & $v$ & & & 郎 & (三重大) \\
\hline & 員 & 家 & 田 & 1 & 之 & (名古星大) \\
\hline
\end{tabular}

\section{1.まえがき}

ポリフッ化ビニリデン $\left(\mathrm{PVF}_{2}\right)$ は、, スピーカ, ヘッ ドホン, マイクロホンなと゚の電気晋筧変換器や超音波

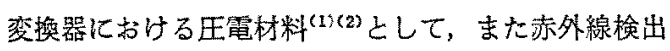
器における焦電材料 ${ }^{(3)}$-(5) टして有機高分子材料の特 長を生かした用途の開発が期待され，既にとの一部は 実用化されている。また，最近 $\mathrm{PVF}_{2}$ はその高い䙵電 率加ら高エネルギー密度コンデンサ材料としてあ注目 されている(6)。このような電気・電子工学的応用の应 大に伴って，その压電性(1)(2)，焦電性 ${ }^{(3) \sim(5)}$ および誘 電特性 (7は多くの研究者によって調べられている。し かしながら，これらの䚽特性を有効に応用守るために

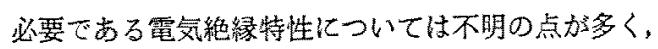
特に總緑破壊特牲に関してははとんど報告されていな W。

筆者らば， $\mathrm{PVF}_{2}$ の宝温汃ら $150^{\circ} \mathrm{C}$ までの温度領域

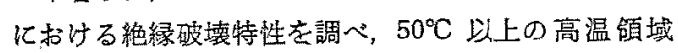

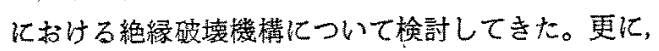

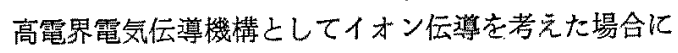

Dielectric Breakdown of Poly (Vinylidene-Fluoride) in High Temperature Region and its Analysis by Numerical Calculation. By Masayuki Hikita, Member (Department of Electrical Engineering, Nagoya University), Masayuki Nagao, Member (Department of Electrical and Electronic Engineering, Toyohashi University of Technology). Goro Sawua, Member (Department of Electronic Engineering, Mie University) \& Masayuki leda, Member (Department of Electrical Engineering, Nagoya Univeisity).

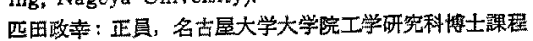

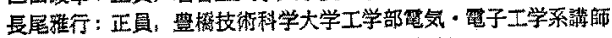

沢 五郎 : 正員，三垂大学工学部電子工学科教授

家田正之: 正貝, 名古屋大学工学部需気工学科教授
ついて，絶縁破壊の理論值と実測继との此較加らイオ ン伝導のパラメータの評洒を宁なってきた。てれらの 一部は概に刮に報告した ${ }^{(8)}$ 。本諭文では, まず $\mathrm{PVF}_{2}$

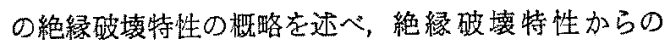
イオン伝導のパラメータの評価について迹へた後,

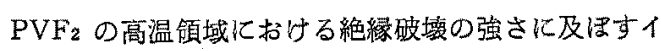
オン伝尊の各バラメータの影響について明ら加し た。また熱解離に対する電界の影慜として, Poole. Frenkel 効果を考慮に入れたイオン伍導の場合につい てす同様な倹討を行なった。

\section{2. 絶縁破填特性}

絶縁破壊特性につつては一部を既に報告したが(8)，

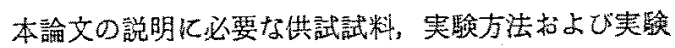
結果の概要を以下㯈へる。

$\mathrm{PVF}_{2}$ \& $\left(\mathrm{CH}_{2-} \mathrm{CF}_{2}\right)_{n}$ の分子式をすつ結羅性高分子 である。その結晶構造仙は，大別して $\alpha$ 形敌よひ $\beta$ 形 結晶の2 種類がある ${ }^{(9)} 。 \beta$ 形結晶は一軸延伸により得 られ，乙の形の結晶を含むフィルム加ら作られたエレ クトレットが珐電性を示す(10)。また $\beta$ 形結晶は，主 銷が平面ジグザグ满造を成して極性基 CF の大きな双 極子モーメントが同一方向を向いた極性結昆であり， その格子定数は， $a=8.58 \AA ， b=4.91 \AA$ および $c=$ $2.56 \AA$ でる。一方， $\alpha$ 形結晶山主鎖がらせん状に

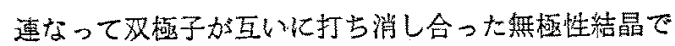
あり，之の格子定数は $a=4.96 \AA ， b=9.64 \AA$ 打之 び $c=4.62 \AA$ である。供試試料は， $\alpha$ 形および $\beta$ 形 結晶の雨者を含む二軸延伸ポリフッ化ビニリデン（ク レハ $\mathrm{KF}$ フィルム) である。ての結晶化度は約 $50 \%$ 


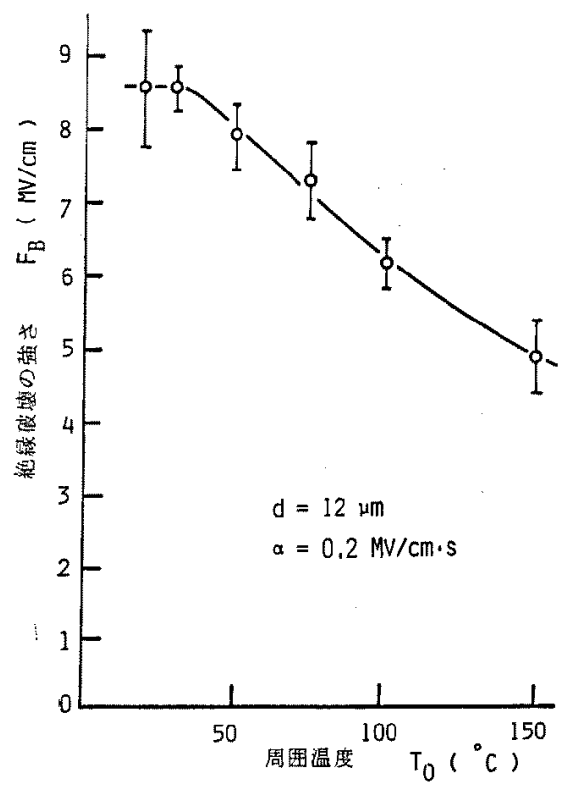

第 1 図 絶縁破䁲の強さの温度依存性

Fig. 1. Temperature dependence of electric strength.

であり，厚さ $d$ は約 $12 \mu \mathrm{m}$ および約 $25 \mu \mathrm{m}$ である。 試料を黄銅製の球一平板電極系にはさみ，それを所定 の温度に保たれたシリコーン油（信越化学 KF-965, $100 \mathrm{cs}$ ) に浸せきした。浸せき 5 分後に各種の電界上 昇率 $\alpha$ の正極性の直線状上昇電王を印加し，絶縁破 壊値の測定を行なった。

絶縁破䏅特性には次の特徽が見られる。厚さ約 12 $\mu \mathrm{m}$ の $\mathrm{PVF}_{2}$ フィルムの絶縁破壊の強さ $\left(F_{B}\right)$ は, 室温付近で $8 \mathrm{MV} / \mathrm{cm}$ 以上の非常に高い值を示すが, $50^{\circ} \mathrm{C}$.以上では温度と共化低下し，150 ${ }^{\circ} \mathrm{C}$ では約 $5 \mathrm{MV}$ / $\mathrm{cm}$ となる(第 1 図)。本実坥の電界上昇率の範囲 $(\alpha$ $=0.08 \sim 0.8 \mathrm{MV} / \mathrm{cm} \cdot \mathrm{s})$ では，室温におりる $F_{B}$ は $\alpha$ 飞依存しないが，500 以上では $F_{B}$ は $\alpha$ の增加と 共に上昇する(第 2 図)。 $F_{B}$ は室温では厚さの増加と 共に低下するが，50 以上では厚さ依存性がなくな る(第 3 図)。

$F_{B}{ }^{\prime}$ の温度依存性により，温度領域は室温 $\sim 50^{\circ} \mathrm{C}$ と $50 \sim 150^{\circ} \mathrm{C}$ に分讨られる。 $F_{B}$ が温度に宬存しない低 温側の温度領域における絶縁破壊機構は，電子的破壊 過程(11)が考えられるが，本論文ではてれ以上澡く議論 女ず，以下 $50^{\circ} \mathrm{C}$ 以上の温度領域の $F_{B}$ について検討 する。

温度の上昇之共に $F_{B}$ が低下する絶縁破壊機構とし ては，純熱破塄過程，電気一機械的破壊過程および無 定形物質に刘する Fröhlich の電子熱破壞過程(1)があ

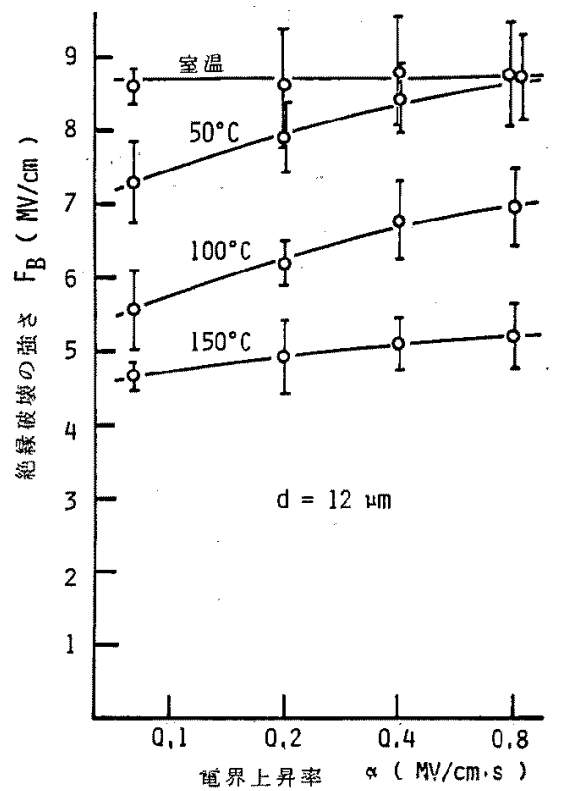

第 2 図 絶縁破境の強さと電界上昇率の関係

Fig. 2. Relation between electric strength and rising rate of applied electric field.

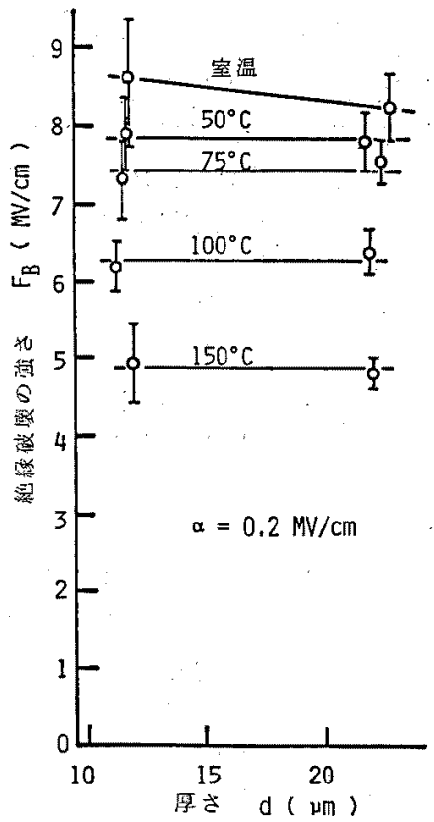

第 3 図 絶縁破壊の強さの厚さ依存性

Fig. 3. Thickness dependence of electric strength.

る。乙れらのうち電気一機械的破壊過程 ${ }^{(12)}$ による $F_{B}$ の理論阡算值は， $20^{\circ} \mathrm{C}$ 加ら $100^{\circ} \mathrm{C}$ の温度範囲におけ るヤング率 $0.8 \sim 1.9 \times 10^{-9} \mathrm{~N} / \mathrm{m}^{2}$ および比誘電率 9.4 
〜13.8 から評価すると 32〜15 MV/cm となった。と の值は测定值に比べ 3 4 倍高い。次に，霄界印加時 間が電子熱破壊理論におりる破壊痋机時間の上限と考 えら机る $10^{-7} \sim 10^{-8} \mathbf{s}^{(13)}$ 上りる非常に大きい化すか わらず， $F_{B}$ が電界上昇率に依存している。従って, こ机を電子熱破壊で理解することは图難である。以上

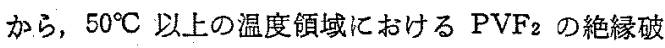
壊機構としては，純熱破壊過程が支配的であると考え られる。更に， $F_{\boldsymbol{B}}$ が厚さに依存しないので，結局

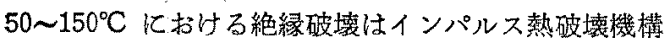
によるもの上考えられる(14)。

純熱破壊の基本式加方，熱放散項を算視することに よって，次のインパルス熱破髙の基本式が得られる。

$$
C_{v} \frac{d T}{d t}=j F .
$$

ここで, $C_{v}$ : 単位体積あたりの比熱, $j:$ 電 流密度, $t:$ 時閖, $F$ : 電界, $T$ : 試料の温度 また, 破壊過程中の温度 $T$ と区別するために，周囲 温度または初期温度を Toとする。

\section{3. 絶縁破垶特性からのイオン伝導の パラメータの評価}

\section{〈3.1〉イオン密度が電界に依存しない場合}

$F_{B}$ が試料厚に依存しないことは，一方では破墑前 駆電流がある電界の下では試料厚に依存せずバルクの 性質によるととを示している。てのような性質を示す 電気伝導機構のう方，高温を対象としているすでイオ ン性伝尊を仮定するととは不合理ではない。まず，イ オン密度が電界の影響を受けない場合を考える。との ときイオン伝導に対する電流密度 $j$ は次式で与えられ る。

$$
j=2 q n 2 \nu_{0} \lambda_{i} \exp \left(-\frac{U}{k T}\right) \sinh \left(\frac{q \lambda_{i} F}{k T}\right)
$$

ここで, $q$ : イオンの電荷, $n:$ イオン密度, Lo: イオン振動数， $2 \lambda_{1}:$ イオンホッピング 距離, $U$ : 電位障壁, $F$ : 電界, $k:$ ボルツ マン定数

一方,イオン密度は，電界の影響を無視すると

$$
n=A N_{0}^{1 / 2} \exp \left(-\frac{W}{2 k T}\right)
$$

ここで，A：定数，No：1オン解離性物質の

密度, $W$ : 解踓エネルギー で与えられるので，(2)式は

$$
j=j 0 \exp \left(-\frac{\phi}{k T}\right) \sinh \frac{q \lambda_{i} F}{k T}
$$

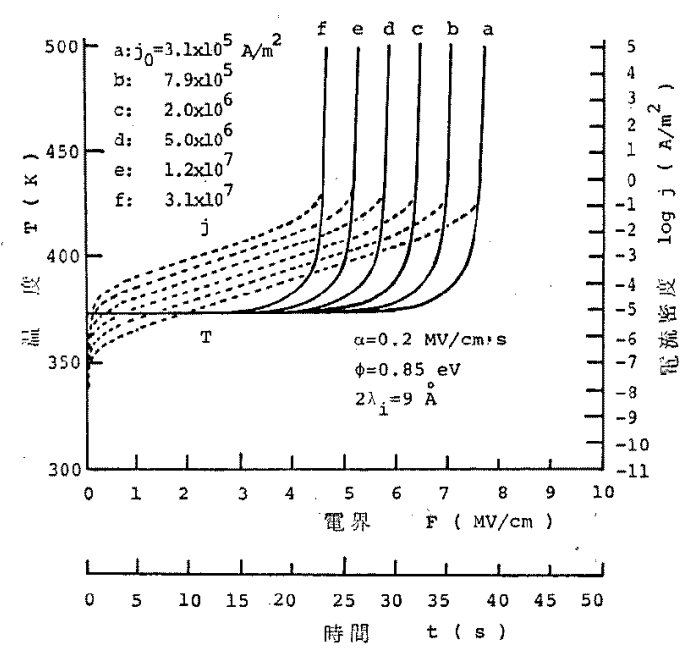

第 4 図種々のjoに対する $T$ および $j の$ 数值計算例

Fig. 4. Examples of numerically calculated values of $T$ and $j$ for different values of $j o$.

ただし， $j_{0}=2 q A V \overline{N_{0}} \nu_{0} 2 \lambda_{i} ， \phi=U+W / 2$ となる。

本実験のように，印加電界加時間と共に直線的に上 昇方る場合，電界 $F$ は $F=\alpha t$ ( $t$ ：時間) 之表わされ るので，(1)式は次のように変形される。

$$
\frac{d T}{d F}=\frac{j F}{C_{v} \alpha}
$$

な打 $\mathrm{PVF}_{2}$ の場合, $C_{v}=2.43 \times 10^{6} \mathrm{~J} / \mathrm{K} \cdot \mathrm{m}^{3}$ であ $3^{(15)}$ 。(5)式は一定の $\alpha$ 亿対してイオン伝導のパラ

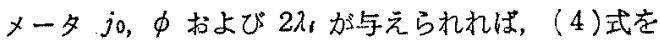
用いて数值計算により解くことができる。RungeKutta-Gill 法(16) 用いて陚料温度 $T$ と電流密度 $j$ を電界の関数として数值計算を行なった。

その結果の一例として, $\phi=0.85 \mathrm{eV}, 2 \lambda_{i}=9 \AA$ とし て，種々の值の $j_{0}$ に対して計算した場合を第 4 図に 示す。同四からわかるように，温度 $T$ は $F$ が上昇し てす初期には上昇せず，絶緑破壊電界の近くで急激に 上昇する。乙の急激な温度上昇の形は $\phi$ に大きく依存 し， $\phi$ が大きくなるとこの上昇の仕方がより急しゅん となる。それゆえに $\phi$ の大きい場合には，絶緑破壊に

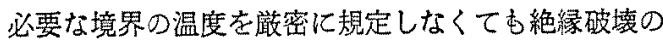
強さを決定することがきでる。ここでは，便宜上，破 壊の境界温度 $T_{m}$ を $\mathrm{PVF}_{2}$ の尉点 $180^{\circ} \mathrm{C}$ とし, $T_{m}$ に達したときの電界 $F$ を紿緣破壊の強さの理論值と した。

次化，絶縁破罗の強さの理論值をその実測值に一政 させるととにより，イオン伝導のパラメータの評洒を 試みた。まず， $T_{0}=100^{\circ} \mathrm{C}$ のときの $F_{B}$ と $a$ の関係 


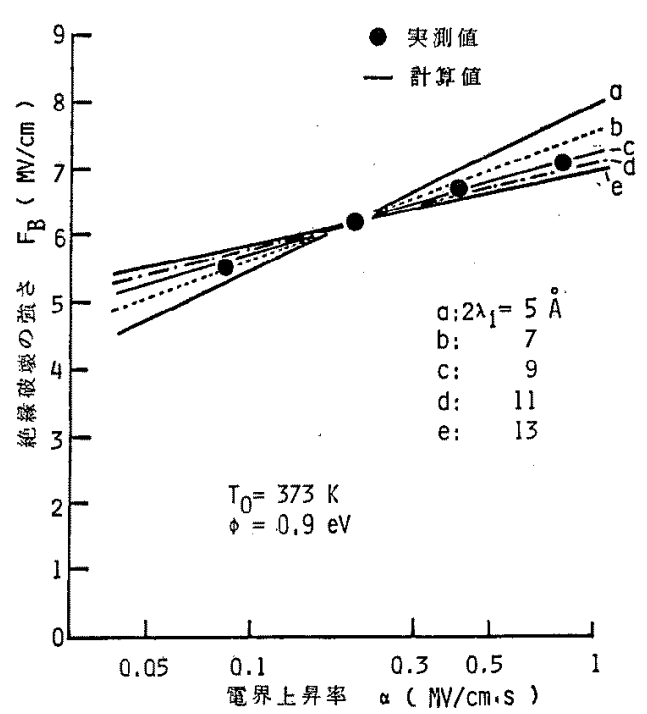

第 5 図種々の $2 \lambda_{i}$ 亿対する $F_{B}-\alpha$ 特性の 計算例 (Poole-Frenkel 效果 を考慮しない場合)

Fig. 5. Examples of calculated values of $F_{B}$ as a function of $\alpha$ with a parameter of $2 \lambda_{i}$ without Poole-Frenkel effect.

を $2 \lambda_{i}$ をパラメータにして求めた。この計算に执いて は， фを一定とし各々の $2 \lambda$ 、付して $\alpha=0.2 \mathrm{MV} /$ $\mathrm{cm} \cdot \mathrm{s}, T_{0}=100^{\circ} \mathrm{C}$ のときの計算值が実測值と一致す るようにjoを選んだ。このような計算を幾つかの異 なった値の $\phi$ に対して行なった。

この結果の一例を $\phi=0.9 \mathrm{eV}$ の場合について第 5 図示す。同図に狲てて、印は実测值を示す。次 に, $F_{B}$ の試料の初期温度 $T_{0}$ 依存性を種々の $\phi$ に対 して計算した。このとき $2 \lambda i$ を一定とし，joを各々 の $\phi$ に対して前述の場合と同様な方法で変化させて 計算を行なった。第6図にその一例として $2 \lambda_{i}=9 \AA$ のときの結果を示す。第 5 図，第6図における $\phi=$ $0.9 \mathrm{eV}$ および $2 \lambda_{i}=9 \AA$ は, 結果として実験值と計算 曲線が適合する場合のパラメータの值である。以上か ら, $2 \lambda_{i}=9 \AA, \phi=0.9 \mathrm{eV}$ 捄よひ $j_{0}=1.2 \times 10^{7} \mathrm{~A} / \mathrm{m}^{2}$ のときに実測值と理論值が良く一致することがわか る。

次に，以上の計算により評価したイオン伝導のパラ メータの值と実測の導電電流との対応について検討し てみる。 $\mathrm{PVF}_{2}$ フィルムにステップ電圧を印加すると 電流は長時間にわたって減衰し，また試料間でかなり のばらつきを示した。てれらの不確実さのために，電 導の測定からパラメータ $j 0, \phi$ 执よび $2 \lambda_{i}$ を評洒する ことは実際には困難であった。理諭的には $2 \lambda_{i} は(4)$ 式を用いて $j-F$ 特性から得られ，また $j 0$ は得られ

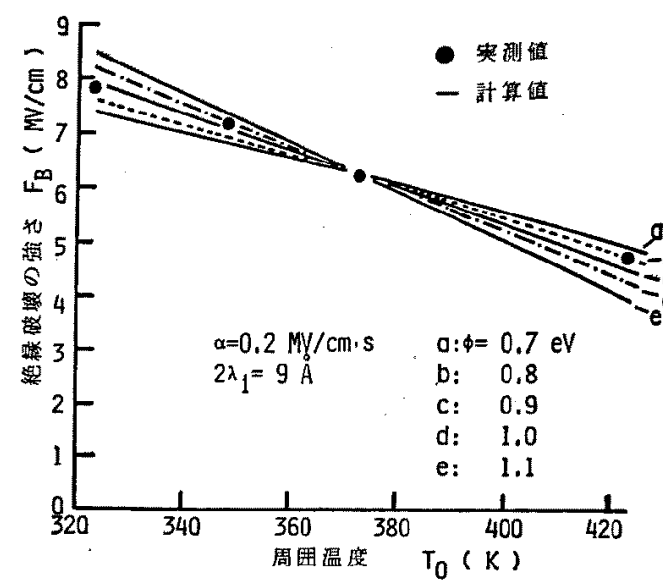

第 6 図種々の $\phi$ 亿対する $F_{B}-T_{0}$ 特性の 計算例 (Poole-Frenkel 効果 を考虑しない場合)

Fig. 6. Examples of calculated values of $F_{B}$ as a function of $T_{0}$ with a parameter of $\phi$ without Poole-Frenkel effect.

た $2 \lambda_{i}$ 老用いて $\log j-1 / T$ 特性の外そうから求めるて とができる。しかしながら，申老決定する $\log j-1 / T$ 特性の項きのわずかな変化によって $j_{0}$ は大幅化変化 する。

筆者らは, ポリエチレンについて多くの測定者によ って得られた導電率を整理すると, pre-expotential factor と活性化エネルギーの問に見かけ上 compensation rule が成立するととを報告した(17)。このように 導電電流の不確実さが大きい場合には，joと $\phi$ を独 立に比較するよりあ一定の温度および電界における電 流密度を比較するほうが意味があると考えられる。乙 のような観点加ら, 温度 $100^{\circ} \mathrm{C}$, 電界 $1 \mathrm{MV} / \mathrm{cm}$ にお

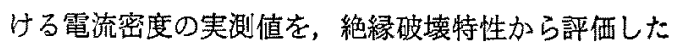
パラメータ $\left(\phi, j_{0}, 2 \lambda_{i}\right)$ を用いて計算した值と比較し てみる。その計算值は $1.7 \times 10^{-5} \mathrm{~A} / \mathrm{m}^{2}$ であった。一 方, 電流密度の実測值は, 電圧印加 10 分後で約 $2 \times$ $10^{-4} \mathrm{~A} / \mathrm{m}^{2}$ であり，計算値より一けた大きい。てれは 今後検討を要する点であるが，現時点においては導電 電流よりも電界依存性が小さい吸収電流成分が実測值 に含まれているのではないかと考えられる。

〈3.2〉 Poole-Frenkel 効果を考虑した場合 前 節ではイオン密度に対する電界の影響を無視したが， ここでは，電界による解離エネルギーの低下を考えた Poole-Frenkel 効果を考慮に入れて，前節と同様な検 討を行なう。Poole-Frenkel 効果を考慮すると，熱的 に平衡状態にある熱解離イオン密度 $n$ は(3)式の代わ りに次式で与えられる。 


$$
n=A N_{0}^{1 / 2} \exp \left(-\frac{W-\beta_{P F} F^{1 / 2}}{k T}\right)
$$

ただし， $\beta_{P F}=\left(q^{3} / \pi \varepsilon_{0} \varepsilon_{r}\right)^{1 / 2}, \quad \varepsilon_{0}:$ 真空の䚷電

率, $\varepsilon_{r}:$ 出誘電率

なお、 $q$ は1価のイオンとする。このとき，電流密度 $j \notin$

$$
j=j_{0} \exp \left(-\frac{\phi-\left(\beta_{P F} / 2\right) F^{1 / 2}}{k T}\right) \sinh \left(\frac{q F \lambda_{i}}{k T}\right)
$$

とな右。(7)式を用いて，〈3・1〉節と同様にして数值 計算により(5)式を解いた。

一般に， $\beta_{P F}$ に含まれる $\varepsilon_{\tau}$ として高周波側の極限 值加とられる場合が多いが，多くの電位障壁をホッピ ングしながら解離する場合には，双極子の配向分極の 影響は必ずしす無視できないと考元られる。従って， ここでは種々の配向分極を含んだ $\varepsilon_{r}$ の値に対して順 次検討した。周波数 $1 \mathrm{kHz}$ における 3.0 であるが，ガラス転移に対応する約 $-25^{\circ} \mathrm{C}$ 以上 では琶定形領域の配向分極を含むようになって約 10 となる。更に，それは約 $80^{\circ} \mathrm{C}$ 以上では結晶領域の配 向分極を含むようになって約 14 となる。こ机をると に， $\varepsilon_{r}$ として 14，10 执よび 3 亿対応する $\beta_{P F}$ の值 $2.03 \times 10^{-5}, 2.40 \times 10^{-5}$ および $4.38 \times 10^{-5} \mathrm{eV} \cdot \mathrm{m}^{1 / 2}$ / V1/2 用いて計算を行なった。

第 7 図および第 8 図は， $\varepsilon_{r}=14$ の場合における $F_{B}$ 亡 $\alpha$ の関係および $F_{B}$ と $T_{0}$ の関係の一例をそ れぞれ示す。両図に扔ける計算值と実測值（畉）が 一致するパラメータとして, $2 \lambda_{i}=4 \AA ， \phi=0.9 \mathrm{eV}$ お よびjo $=6.5 \times 10^{5} \mathrm{~A} / \mathrm{m}^{2}$ が得られた。 $\varepsilon_{r}=10$ の場合に 6 $\varepsilon_{r}=14$ の場合とはとんど等しい $2 \lambda_{i} ， \emptyset$ および $j 0$ の値が得られた。しかし， $\varepsilon_{r}=3$ の場合には $2 \lambda_{i}<1$ 丸となり，乙の值は固体檴造からみて物理的に考え 難く， $\dot{\varepsilon_{r}}=3$ を $\beta_{F F}$ に用いることは不合理であると考 えられる。との点加らみて， $\beta_{P F}$ に対して双極子の配 向分極成分を含んだ である。

そこで，イオンが解離する時間内に双極子の配向の 絀和が生ずるかどうかについて吟味してみる。PooleFrenkel 効果考考えたとき，イオンの中性状態方ら電 位障壁の最大德までの距離 $r_{\max }$ は,

$$
r_{\max }=\sqrt{\frac{q}{4 \pi \varepsilon_{0} \varepsilon_{r} F}}
$$

で与えられ(18)，日加電界 $F$ により変化する。 $\varepsilon_{\mathrm{r}}=14$ の場会の $r_{\mathrm{m}}$ の值を第 1 表化示す。絶縁破壊電界近 くの高電界では， $r_{\max }$ は前述の計算から求めた $2 \lambda_{i}=$

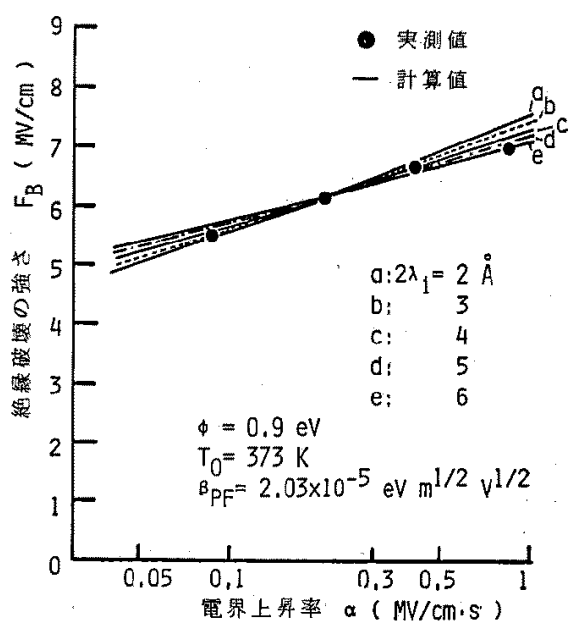

第 7 図種々の $2 \lambda_{i}$ K対する $F_{B}-\alpha$ 特牲 の計算例 (Poole-Frenkel 勃果 を考虑した場合)

Fig. 7. Examples of calculated values of $F_{B}$ as a function of $\alpha$ with a parameter of $2 \lambda_{i}$ with Poole-Frenkel effect.

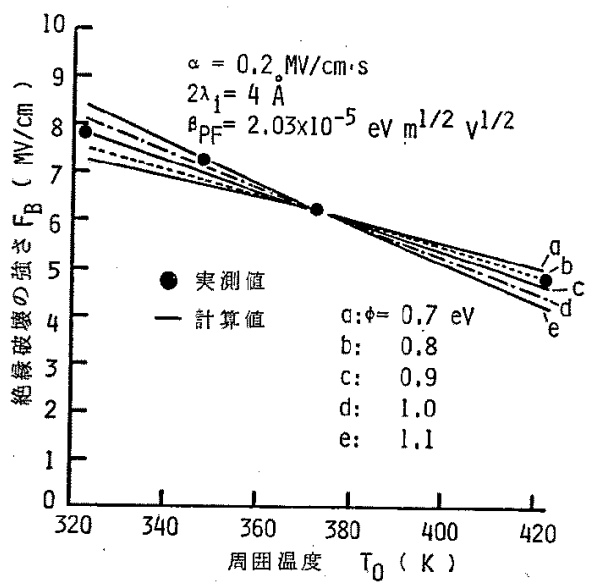

第 8 图種々の $\phi$ 亿対する $F_{B}-T_{0}$ 特性 の計算例 (Poole-Frenkel 効果 を考虑した場合)

Fig. 8. Examples of calculated values of $F_{B}$ as a function of $T_{0}$ with a parameter of $\phi$ with Poole-Frenkel effect.

$4 \AA$ と同じオーダの大きさとなる。

次に，イオンホッポングひん度りは反応速度猃的 に解鄱すると，次式の上うに与えられる(19)。

$$
\nu=\frac{k T}{h} \exp \left(-\frac{\Delta F^{*}}{k T}\right)
$$

ただし，

$$
\Delta F^{*}=\Delta H^{*}-T \Delta S^{*}
$$


第 1 表 $r_{\max }$ の值

Table 1. Values of $r_{\max }$

\begin{tabular}{l|c|c|c|c}
\hline$F(\mathrm{MV} / \mathrm{cm})$ & 0.01 & 0.1 & 1 & 6 \\
\hline$r_{\max }(\AA)$ & 101 & 32 & 10 & 4.1 \\
\hline$\left.\varepsilon_{r}=14\right)$ &
\end{tabular}

第 2 表 $\Delta S^{*}$ と $\nu$ の関係

Table 2. Relation between $\Delta S^{*}$ and $\nu$.

\begin{tabular}{l|r|r|c|c|c}
\hline$\Delta S^{*}(\mathrm{cal} / \mathrm{mol} \cdot \mathrm{K})$ & 0 & 10.3 & 19.5 & 60 & 300 \\
\hline$v(1 / \mathrm{s})$ & 5.42 & $10^{3}$ & $100 \times 10^{\mathrm{s}}$ & $7.54 \times 10^{19}$ & $2.81 \times 10^{68}$ \\
\hline$U=0.9 \mathrm{eV}, \quad T=373 \mathrm{~K}$
\end{tabular}

ここで，h: プランク定数， $\Delta F^{*}$ : 活性化自 由エネルギー, $\Delta H^{*}$ : 活性化エネルギー,

$\Delta S^{*}:$ 活性化エントロピー

一方, 山は(2)式吕ら

$$
\nu=\nu_{0} \exp \left(-\frac{U}{k T}\right)
$$

なる関倸があり，(9)，(10) 式と（11）式から $\nu_{0}=$ $(k T / h) \exp \left(\Delta S^{*} / k\right), U=\Delta H^{*}$ の関係がある。炕は $W$ を含んでいるので $U$ の值は不明であるが, $\phi=U$ とすれば $\exp (-U / k T)$ の最小の見積りとなる。

第 2 表は前に求めた $\phi=0.9 \mathrm{eV}$ を使っ $て, U=0.9$ $\mathrm{eV}, T=373 \mathrm{~K}$ における $\Delta S^{*}$ と山の関係を示す。い ま粗い近似として，イオンは距離 $2 \lambda_{i}$ 離れた幾つかの 山をホッピングしながら解離のポテンシャルの頂上に 達すると考えると，解離佂要する時閒は $\left(r_{\mathrm{max}} / 2 \lambda_{i} \cdot \nu\right)$ となる。との時間が双極子の緩和時間上り長い必要が ある。第 1 表から，破填電界の極るて近傍ではホッピ ング距離と $r_{\max }$ とはほ等しくなり上述の考元方は適 用し難いが，破壊電界より少し低い電界ではその適用 の可能性がある。双極子の緩和時間に温度の上昇之共 に短くなるが，その長時間側の見積りとして，1kH に対応する $\mathrm{ms}$ 程度を若えて，( $\left.r_{\mathrm{max}} / 2 \lambda_{i} \cdot \nu\right)$ を $\mathrm{ms}$ 程 度以上とするためには $\Delta S^{*}$ は $10.3 \mathrm{cal} / \mathrm{mol} \cdot \mathrm{K}$ であれ ば良い。 $\mathrm{PVF}_{2}$ のイオン妘導位対する $\Delta S^{*}$ の值を物 理的に理解することは現状では難しい。しかし，氷の 双極子の楥和に対する $\Delta S^{*}$ の值加 $17.6 \mathrm{cal} / \mathrm{mol} \cdot \mathrm{K}$ であるととを考えれば，上述の $\Delta S^{*}$ 值は物理的に不 合理とは言劣ない。

以上のように， $\varepsilon_{r}$ として 10〜14をよって PooleFrenkel 効果の有無によってイオンホッピング距離は それぞれ9Aおよび $4 \AA$ となったが, 前述の格子定 数から考えて，いずれがより妥当かは判定できない。 一方, ここで, 評価したパラメータをあとに算出した $100^{\circ} \mathrm{C}, 1 \mathrm{MV} / \mathrm{cm}$ に书外万電流密度は， $7.1 \times 10^{-6} \mathrm{~A} / \mathrm{m}^{2}$
となり，てれは前述の Poole-Frenkel 効果を考慮しな い場合の值上り更に小さく，実測值よりも約二けた小 さくなる。また，以上の Poole-Frenkel 勃果を考虑し た場合には，破填電界近傍では問題があるばかりでな く，絶縁破填過程加(6)式の上う解離平衡を保ちな がら進行するかどうかなど不明な点すある。以上から 考えて，破壤過程中の熱解離に対する電界の影響は， 詳細には(6)式のような単純な形ではなく，あっと複 雑なもの之思われる。このように，現段階ではPooleFrenkel 効果を考虑した場合としない場合のいずれが 妥当であるかを明白にするてとは困難であるので，以 下では両者を併置して議論を進めることにする。

\section{4. 絶縁破壊の強さ $\boldsymbol{F}_{B}$ に及ぼすイオン伝寻 の各パラメータの影響}

高温領域における $\mathrm{PVF}_{2}$ の電界上昇率 $0.08 \sim 0.8$ $\mathrm{MV} / \mathrm{cm} \cdot \mathrm{s}$ の直線状上㫒電圧に対する絶緑破䏅が，1 ンパルス熱破壊によるととをすとにして，絶縁破壊の 計算值と実験値との比較よりイオン伝導のパラメータ を評価した。この結果をもとに，本章では $\mathrm{PVF}_{2}$ の高 温領域におりる絶縁破壊の強さに及洔すイオン伝導の 各パラメータの影響を検討する。

まず，イオン密度が電界に依存しない場合を考え る。パラメータ $j_{0}$ をイオン密度に関する成分と，1 オン跳躍距離の成分に分割して考えるため，(4)式を (5)式へ代入して次のような形にする。

$$
\frac{d T}{d F}=\frac{J_{1}}{C_{v}} 2 \lambda_{i} \exp \left(-\frac{\phi}{k T}\right) \sinh \left(\frac{q F \lambda_{i}}{k T}\right)
$$

ただし, $J_{2}=j_{0} / \alpha \cdot 2 \lambda_{i}=2 q A V \overline{N_{0}} \nu_{0} / \alpha \cdot 2 \lambda_{i}$ である。 (12)式に拈いて， $\phi ， 2 \lambda_{1}$ 扰よひ $J_{1}$ の三つのパラメー タのうちいずれか二つをそれぞれ前章で求めた值 $\phi=$ $0.9 \mathrm{eV}, 2 \lambda_{i}=9 \AA$ 扰上び $J_{1}=6.7 \times 10^{8} \mathrm{~A} \cdot \mathrm{s} / \mathrm{V} \cdot \mathrm{m}^{2}(\alpha$ $=0.2 \mathrm{MV} / \mathrm{cm} \cdot \mathrm{s})$ に固定し, 残りの一つを変化させて 計算を行なった。

第9図( a), (b)はそれぞれ $T_{0}=323 \mathrm{~K}$ およひ 373 $\mathrm{K}$ に扔いて，各パラメータを独立に变化させた場合の $F_{B}$ の変化を示す。四中の曲線は，（）内に示すパラ メータを横軸に表わされた範围内で变化させたよきの

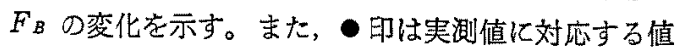
である。同因から，Jおおび $2 \lambda_{1}$ を減少させ $\phi$ を増 加させることができれば，高温領域における $F_{B}$ が向 上することがわかる。第 3 表は， $F_{B}$ を $1 \mathrm{MV} / \mathrm{cm}$ 上 异させるために必要なパラメータの変化分を示す。

次に, Poole-Frenkel 形熱解離を考虑した場合につ いて第 3 表之同樣にして求めた結果を第 4 表に示す。 


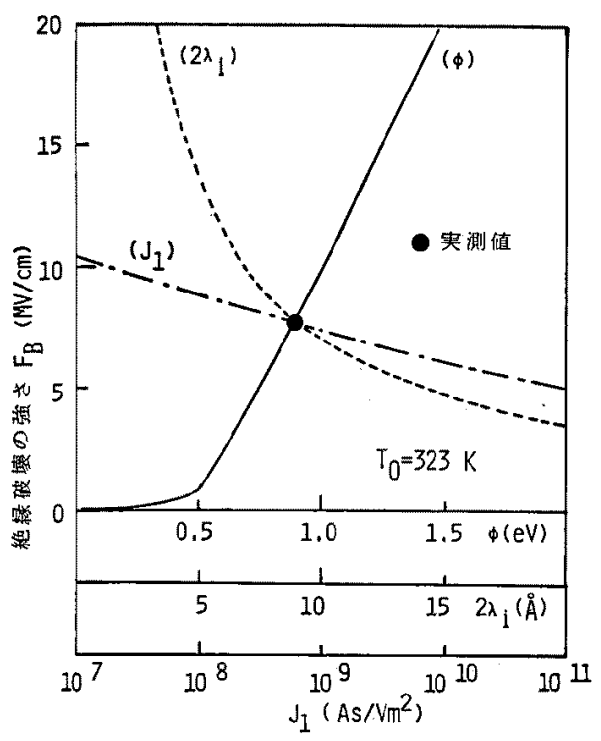

(a)

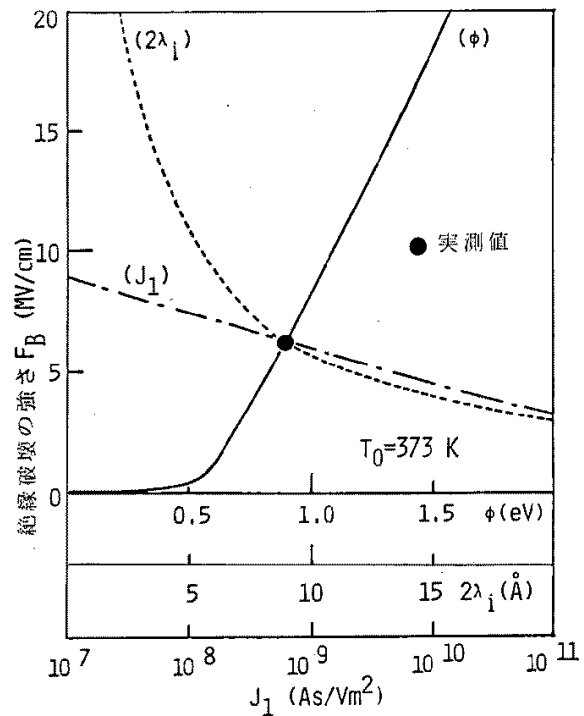

(b)

第 9 图 イオン伝導のパラメータ $J_{1}, 2 \lambda_{i}, \phi$ による絶縁破壊の強さの変化（Poole-

Frenkel 効果を考琶しない場合）

Fig. 9. Variation of electric strength with the ionic conduction parameters $J_{1}, 2 \lambda_{i}$ and $\phi$ without Poole-Frenkel effect.

なお，同表においては $\beta_{P F}=2.03 \times 10^{-5} \mathrm{eV} \cdot \mathrm{m}^{1 / 2} \mathrm{~V}^{1 / 2}$ とし，丰測值に対応するパラメータは $\phi=0.9 \mathrm{eV}, 2 \lambda_{i}$ $=4 \AA$ および $J_{1}=8.1 \times 10^{7} \mathrm{~A} \cdot \mathrm{s} / \mathrm{V} \cdot \mathrm{m}^{2}$ である。

第 3 表，第 4 表加ら，Pooel-Frenkel 効果の考慮の 有無に加からず次のととがわかる。一定の $\alpha$ に対し て, $J_{1}$ は $N_{0}^{1 / 2}$ に比例するので, $F_{B}$ を $1 \mathrm{MV} / \mathrm{cm}$ 上
第 3 表 $F_{B}$ を $1 \mathrm{MV} / \mathrm{cm}$ 上昇させるのに必要な イオン伝導のパラメータの变化分 $\Delta \phi, \Delta 2 \lambda_{i}, \Delta J_{1}$

(Poole-Frenkel 効果を教虑しない場合)

Table 3. The changes $\Delta \phi, \Delta 2 \lambda_{1}$ and $\Delta J_{1}$ in ionic conduction parameters required for increasing $F_{B}$ by $1 \mathrm{MV} / \mathrm{cm}$ without Poole-Frankel effect.

\begin{tabular}{c|c|c|c}
\hline & $\Delta \phi$ & $\Delta 2 \lambda_{i}$ & $\left(J_{1}+\Delta J_{1}\right) / J_{1}$ \\
\hline $323 \mathrm{~K}$ & $0.05 \mathrm{eV}$ & $-1 \AA$ & 0.15 \\
\hline $373 \mathrm{~K}$ & $0.05 \mathrm{eV}$ & $-1.5 \AA$ & 0.15 \\
\hline
\end{tabular}

第 4 表 $F_{B}$ を $1 \mathrm{MV} / \mathrm{cm}$ 上昇させるのに必要な イオン伝歁のパラメータの留化分 $\Delta \phi, \Delta 2 \lambda_{i}, \Delta J_{1}$

(Poole-Frenkel 好果を考虑した場合)

Table 4. The changes $\Delta \phi, \Delta 2 \lambda_{i}$ and $\Delta J_{1}$ in ionic conduction parameters required for increasing $F_{B}$ by $1 \mathrm{MV} / \mathrm{cm}$ with Poole-Frenkel effect.

\begin{tabular}{c|c|c|c}
\hline & $\Delta \phi$ & $\Delta 2 \lambda_{i}$ & $\left(J_{1}+\Delta J_{1}\right) / J_{1}$ \\
\hline $323 \mathrm{~K}$ & $0.05 \mathrm{eV}$ & $-1 \AA$ & 0.15 \\
\hline $373 \mathrm{~K}$ & $0.05 \mathrm{eV}$ & $-1.2 \AA$ & 0.15 \\
\hline$\varepsilon_{r}=14$ & &
\end{tabular}

䒜させるには，熱解離性イオン供給源の密度 No 約を

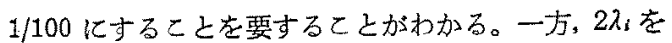

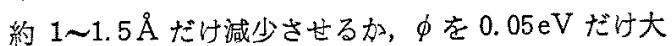
きくすれば $N_{0}$ を約 2 けた減少させるのと同じ効果を $F_{B}$ K与えることがでさることが加る。

このように, $\mathrm{PVF}_{2}$ の高温領域における $F_{B}$ を向上 させるためには，一般に考えられる不純物除去やイオ ン解離性物質の安定化によってイオン密度の減少を図

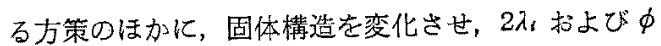
を变化させることも大きな効果を示すすのと期待され

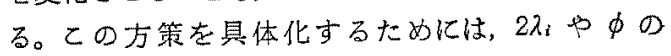
$\mathrm{PVF}_{2}$ 内の構造に対応した微視的な物理的意制を明ら 加にする必要があるが，てれ関して現在， $\alpha$ 形およ ひ $\beta$ 形結晶の含有割合を変化させた試料を用いて更に 検討している。

\section{5.むすび}

直線状上算電任に上る $\mathrm{PVF}_{2}$ の $50^{\circ} \mathrm{C}$ かる $150^{\circ} \mathrm{C}$ までの温度領城におりる絶緣破壊特性はインパルス熱 破壊機構によるととを亦した。次に，イオン伝導を考 え，イソパルス熱破燷の理諭計算を行なった。絶縁破 塄の强さの計算值と奏測值と口比㬵により，イオン伝 導のパラメータ $2 \lambda_{i}$ ， 放よび $j 0$ はそれぞれ $9 \AA$, $0.9 \mathrm{eV}$ 就よ゙ $1.2 \times 10^{7} \mathrm{~A} / \mathrm{m}^{2}$ と評価された。また， 同様のととを Poole-Frenkel 形熱解離を考慮した場合

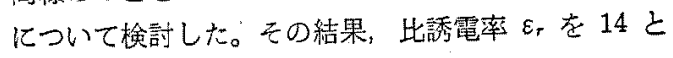


するとき，イオン伝導のパラメータ $2 \lambda_{i} ， \phi$ お上び jo はをれぞれ $4 \AA$ ， $0.9 \mathrm{eV}$ 扣上び $6.5 \times 10^{\mathrm{s}} \mathrm{A} / \mathrm{m}^{2}$ 上評 価された。

最後に，PVF の高温頜域におりる絶縁破壊の強さ の向上に対する指針を得るために，絶縁破壊の強さに 及将すイオン伝算のパラメータの影響汇ついて検討し た。その結果, Poole-Frenkel 効果の考虑の有無に加 加わらず， $\mathrm{PVF}_{2}$ の高温領域における $F_{B}$ を向上させ るためには，通常考えられる不純物除去やイオン解離 性物貿の安定化によってイオン密度の減少を图る力法 のほかに，固体棈造を変化させてイオンホッピング距

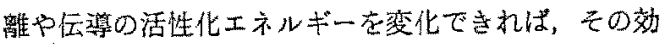
果が大きいことを定量的に示した。との方法を具体化 するためには，PVF2 の圆体構造とイオン伝導のパラ メータの関保を明ら加をる必要があり，この点に関 して現在 $\alpha$ 形亡 $\beta$ 形結昆の含有割合を変化させて検 尌中である。

最後に，試料を提供していただいた㝵羽化学工業 〈株)の関係諸氏に感謝いたします。

(昭和 55 年 5 月 22 日受付)

\section{文献}

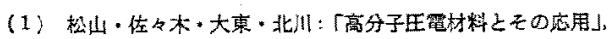
空被志，46，705 (昭 52-7)

(2) M. G. Broadturst; G. T. Davins \& J.E Mckinsery: "Piezoelectricity and ipyroelectricity in polyvinylidene Quoride-A modela!', J. Appl. Phys., 49, 4992 (1978)

(3) G. Pister, M. Abkowitz \& R. G. Crystal: "Pyroelectrieity in polyvinylidene fluoride", ibid,, 44, 2064 (1973)

(4) K. Takahashi, et al. : "Nature of injection processes during poling of poly (vinylidene fluoride) and their relationship to pyroelectricity", ibid., 48. 4694 (1977)

(5) D. K. Das-Gupta \& J. S. Duffy: "Pyroelectricity in polyvinylidene Aluoride", ibid., 50, 561 (1979)

(6) R. Parkez: "Technological developement of high energy density capacitors", Report of NASA, No. NASA CR, 124926 (1976)

(7) S. Osaki, S. Uemura \& Y. Ishida: "Effects of a Static Electric Field upon Dielectric Properties of Foly (vinylidene Fluoxide) and Poly(vinyl Fluoride)", J. Polymer Sci, Part A-2, 9, 585 (1971)

(8) M. Hikita, et al.: "Dielectric breakdown and electrical conduction of poly(vinylidene-Aluoride) in high temperature region", J. Phys, D: Appl. Phys., 13, 661 (1980)

(9) R. Hasegawa, M. Kobayashi \& H. Tadokoro: "Molecular Conformation and Packing of Poly(vinylidene fluoride). Stability of Three Crystalline Forms and the Effect of High Pressure", Polymer J, 3, 591 (1972)

(10) Y. Wada \& R. Hayakawa: "Piezoelectricity and Pyro electricity of Polymers", Japan. J. Appl. Phys., 15, $2041(1976)$

(11) J.J. O'Dwyer: The Theory of Electrical Conduction and Breakdown in Solid Dielectrics (1973) Clarenden Press, Oxford

(12) R. Stark \& C.G. Garton: "Electric Strength of Irradiated Polythene", Nature, 176, 1225 (3955)

(13) J. Artbauer, C. Sc \& J. Griac: "Intrinsic electric strength of polythene in the hightemperature region", Proc. Instn Elect. Engrs, 112, 818 (1965)

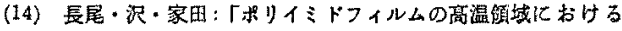

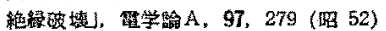

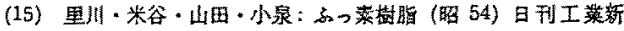
葄社

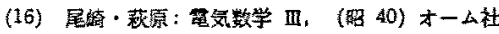

(17) G. Sawa, M. Ieda \& K. Kitagawa: "Relation Between Pre-Exponential Factor and Activation Energy in Dark Conductivity of Polyethylene", Electronics Lett., 10. 50 (1974)

(18) J. Freckel: "Pre-Breakdown Phenomena in Insulators and Electronic Semi-Conductors", Phys. Rev., 54, 674 (1938)

(19) S. Glasstone, K. J. Laidler \& H. Erying: The Theory of Rate Process, (1941) McGrow Hill 